\title{
KEPEMIMPINAN KOMUNITAS KALI CODE DALAM MENGGERAKKAN MODAL SOSIAL
}

\author{
Oleh: \\ Farida Hanum \\ Staf Pengajar FIP UNY
}

\begin{abstract}
Penelitian ini bertujuan untuk menggali informasi dan data mengenai kepemimpinan komunitas Kali Code pasca Romo Mangun dalam menggerakkan modal sosial, untuk keberlanjutan pembangunan pemukiman Kali Code Ledok Gondolayu Yogyakarta.

Penelitian ini memakai pendekatan kualitatif dengan teknik pengumpulan data menggunakan wawancara, observasi, dan dokumentasi. Informan dalam penelitian ini adalah para mantan pimpinan komunitas pasca Romo Mangun termasuk bapak RT yang bertugas saat ini. Untuk keabsahan data dipakai teknik trianggulasi sumber, yaitu meng-crossceck data yang diperoleh dari para informan kepada pihak lain dalam hal ini anggota masyarakat dan tokoh masyarakat yang menjadi anggota komunitas Kali Code.

Hasil penelitian ini menunjukkan bahwa kepemimpinan komunitas Kali Code, semuanya melanjutkan cara dan gaya kepemimpinan yang telah dilaksanakan oleh Romo Mangun, yaitu menanamkan rasa kebersamaan dan kemandirian warga untuk kepentingan bersama. Peran pemimpin dalam menggerakkan modal sosial sangat besar. Pemimpin berdiri di depan memberi keteladanan dan ikut langsung memimpin dan mengarahkan aktivitas. Para pemimpin ini memiliki sikap tegas, namun dalam menggerakkan warga, pemimpin umumnya bersikap persuasif dan mampu menjelaskan manfaat usaha mereka untuk kebaikan bersama. Tipe kepemimpinan mereka kharismatik, yang bersumber dari kepribadian mereka yang sangat dihormati oleh para warga. Sehingga warga rela mengikuti semua yang diarahkan para pimpinan tersebut, dengan demikian modal sosial warga mudah untuk digerakkan.
\end{abstract}

\section{PENDAHULUAN}

Membicarakan Kali Code tidak bisa lepas dari sosok yang sangat dihormati warga dan tokoh yang sangat berperan 
mewujudkan komunitas Kali Code adalah Romo Mangun. Sebelumnya menurut artikel Guinnes (dalam Darwis K., 2002: 21), awalnya penghuni Kali Code adalah para pengembara yang menggelandang dari kota ke kota yang kemudian menetap di pinggir sungai Code. Mereka meninggalkan desa asal mereka sebagian besar karena tidak tahan lagi hidup di desa, ada yang disebabkan tidak memiliki harta apapun lagi, karena desakan ekonomi untuk dapat bertahan hidup, ada yang menjadi pemulung, copet, menjajakan diri, terkucil di desanya dan akhirnya terdampar di ledok Gondolayu. Kebanyakan penduduk ledok Gondolayu (Kali Code) berasal dari luar kota Yogya. Ada yang berasal dari Jawa Timur, seperti dari Pacitan, Jombang, Ponorogo, Surabaya; ada yang dari Jawa Tengah seperti Magelang, Solo, Klaten, Sragen, Purworejo, Wonogiri; ada yang berasal dari kabupaten yang di DIY seperti Wonosari, Kulon Progo, dan Bantul.

Pada tahun 1983, Romo Mangun dan sejumlah kawan relawannya menjadikan ledok Kali Code menjadi "kampung binaan" mereka, setelah tercapainya gentleman agreement antara pemerintah dan tim Romo Mangun. Meskipun Romo Mangun dan kawan-kawan yang bekerja di kampung Code bukan kelompok pemerintah, mereka tidak dapat digolongkan dalam kelompok organisasi non pemerintah (LSM). Mereka bukan sebuah organisasi resmi, bukan pula bagian dari sebuah organisasi resmi. Mereka hanyalah para sukarelawan yang oleh panggilan hati nurani, bersedia bekerja untuk kepentingan kaum miskin tanpa bayaran. Mereka lebih mengutamakan "gerakan ide" atau "gerakan hati nurani" daripada gerakan sosial atau politik yang terorganisir atau terlembaga secara resmi. Landasan moral gerakan ini ialah "berpihak kepada kaum miskin dan terpinggirkan". Romo Mangun dan tim relawannya berkeinginan untuk mengubah cara hidup penduduk Kali Code yang saat itu hidup dalam kemiskinan dan memiliki kebiasaan yang kurang baik dan sehat tidak diakui keberadaannya (penduduk liar) di Kota Yogyakarta. 
Konsep binaan yang diterapkan pada masa Romo Mangun dan kawan-kawan meliputi Bina Manusia, Bina Usaha, dan Bina Lingkungan, yang disebut sebagai Tri Bina. Bina Manusia dimaksudkan untuk meningkatkan pengetahuan, pengertian, dan kesadaran berkeluarga dan bermasyarakat. Bina Usaha untuk meningkatkan taraf hidup dan sarana ekonomi masyarakat. Adapun Bina Lingkungan untuk memperbaiki lingkungan hidup, khususnya di bidang perumahan dan fasilitas umum. Romo Mangun menanamkan pada warga prinsip kemandirian dan kebersamaan tanpa menunggu pertolongan pihak lain ataupun pemerintah. Prinsip modal sosial sangat menonjol dalam kepemimpinan Romo Mangun dalam membina komunitas Kali Code.

Sebagian dari warga penghuni Ledok Kali Code datang ke kota Yogya tanpa uang, tanpa keterampilan, tanpa ilmu. Namun, mereka dapat bertahan hidup, tetapi mereka tak tahu mengapa mereka ada di sana dan bagaimana keluar dari sana. Oleh sebab itu, sangat diperlukan para tokoh pemimpin yang mampu menggerakkan dan mengelola mereka agar mampu hidup layak dalam keterbatasan. Romo Mangun dapat menggerakkan masyarakat ledok Kali Code membangun dengan modal sosial. Modal sosial adalah kumpulan dari hubungan yang aktif di antara manusia, rasa percaya, saling pengertian, dan kesamaan nilai dan perilaku yang mengikat anggota dalam sebuah jaringan kerja dan komunitas yang memungkinkan adanya kerja sama (Cohen D., dan Prusack, 2001).

Adapun Coleman (1994) mendefinisikan modal sosial sebagai "seperangkat sumber daya yang melekat pada hubungan keluarga dan dalam organisasi sosial komunitas dan yang berguna bagi perkembangan kognitif atau sosial anak atau orang yang masih muda. Sumber-sumber daya tersebut berbeda bagi orang-orang yang berlainan dan dapat memberikan manfaat penting bagi anakanak dan remaja dalam perkembangan modal sosial manusia mereka. Sedang Putnam (2000) mengatakan modal sosial adalah jaringan sosial yang memiliki nilai, kontak sosial, seperti 
kepercayaan, norma, dan jaringan, yang dapat meningkatkan efisiensi masyarakat dengan memfasilitasi tindakan-tindakan terkoordinasi, mendorong partisipasi bertindak bersama-sama lebih efektif untuk mencapai tujuan bersama. Emile Durkheim (1933), yang banyak dikenal sebagai tokoh pendiri utama pemikiran sosiologi abad ke-19, secara khusus tertarik pada bagaimana ikatan sosial antarmanusia menjadi simpul yang menyatukan jalinan masyarakat yang lebih luas, di dalam masyarakat ada solidaritas baik mekanis maupun organis. Menurut Durkheim bahwa masyarakat tidak menjadi ikatan atom yang saling berhadaphadapan, melainkan anggotanya disatukan oleh ikatan yang semakin erat dan semakin melampaui momen singkat terjadinya pertukaran tersebut. Ini merupakan inti kehidupan bermasyarakat.

Pembangunan masyarakat dan lingkungan pemukiman Ledok Kali Code Gondolayu yang dipimpin oleh Romo Mangun, dilakukan secara trial and error, tanpa rencana kerja tertulis (Darwis Khudori, 2002). Romo Mangun merupakan inisiator dan relawan yang pertama dan utama yang memiliki inisiatif untuk membangun dan memperbaiki baik sarana fisik maupun sosial para pemukim Ledok Kali Code. Romo Mangun datang ke Kali Code dengan niat melayani kaum miskin dan warga masyarakat yang termarginal dari pembangunan yang ada di Jawa khususnya. Melayani kaum miskin dalam kerangka cinta kasih tidak berarti memenuhi atau membantu memenuhi kebutuhan konsumtif mereka. Mencintai juga berarti menghormati, termasuk menghormati mereka dalam menyelesaikan masalah mereka. Karena itu, melayani kaum miskin tidak berarti memberikan hal-hal atau fasilitas yang membuat mereka tergantung, melainkan membukakan kemungkinan-kemungkinan untuk memecahkan masalah mereka dan untuk mencapai kehidupan yang lebih baik dalam tata sosial yang lebih manusiawi.

Romo Mangun dalam membangun komunitas Kali Code menggerakkan modal sosial yang dimiliki masyarakat di sana. Bermodal rasa percaya (trust) yang sangat tinggi pada sosok Romo 
Mangun maka para individu yang menjadi warga Kali Code dapat ditumbuhkan semangat kerja sama mereka untuk dapat mandiri membangun tempat tinggal mereka agar layak huni. Fukuyama (2002) memberi paparan bahwa kepercayaan adalah harapan yang tumbuh di dalam sebuah masyarakat yang ditunjukkan oleh adanya perilaku jujur, teratur dan kerja sama berdasarkan norma-norma yang dianut bersama. Pada tingkat komunitas sumebr-sumber trust berasal dari norma sosial yang memang telah melekat pada struktur sosial setempat.

Mollering dalam Dharmawan (2002) merumuskan ada 6 (enam) fungsi trust, yaitu:

1. Kepercayaan dalam arti confidence, bekerja para psikolosis individual. Sikap ini memdorong orang berkeyakinan dalam mengambil satu keputusan setelah memperhitungkan resikoresiko yang ada. Dalam waktu yang sama, orang lain juga akan berkeyakinan sama atas tindakan sosial tersebut, sehingga tindakan itu mendapati legitimasi kolektif.

2. Kerjasama, sebagai proses assosiatif dimana trust menjadi dasar terjadinya hubungan-hubungan antar individu dilatarbelakangi rasa saling curiga. Selanjutnya, semangat kerajasama akan mendorong integrasi sosial yang tinggi.

3. Penyederhanaan pekerjaaan, dimana trust membuat meningkatkan efisiensi dan efektivitas kerja kelembagaankelembagaan sosial.

4. Ketertiban Trust berfungsi sebagai inducing behaviour setiap individu yang ikut menciptakan suasana kedamaian dan meredam kemungkinan timbulnya kekacauan sosial.

5. Pemeliharaan kohesivitas sosil trust membantu meningkatkan setiap komponen sosial yang hidup dalam sebuah komunitas menjadi kesatuan yang tidak tercerai berai.

6. Modal sosial Trust berfungsi sebagai penggerak untuk bersamasama membangun kepentingan bersama.

Gagasaan sentral modal sosial adalah bahwa jaringan sosial merupakan aset yang sangat bernilai. Jaringannya memberikan 
dasar bagi solusi sosial karena menolong orang bekerjasama satu sama lain, dan tidak sekedar orang yang mereka kenal secara langsung untuk memperoleh manfaat timbal balik.

Setelah Romo Mangun berpulang, Kali Code tetap menarik perhatian banyak kalangan baik warga yogya maupun luar yogya, bahkan warga mancanegara. Warga komunitas ledok Kali Code yang telah diakui kebudayaannya sebagai bagian unik dari warga Kota Yogya, tetap eksis dalam kehidupan mereka sehari-hari. Penelitian ini bertujuan untuk menggali informasi dan mengungkap realita bagaimanakah gambaran pimpinan komunitas masyarakat Kali Code saat ini (pasca berpulangnya Romo Mangun), mampu menggerakkan masyarakat untuk menghimpun modal sosial. Modal sosial yang bagaimana yang berjalan saat ini di komunitas tersebut.

\section{Cara Penelitian}

Permasalahan yang diajukan dalam penelitian ini lebih mengutamakan permasalahan sosial, maka jenis penelitian yang relevan adalah kualitatif dalam hal ini studi kasus (Kali Code). Penelitian ini diharapkan menggali data sekaya dan sedalam mungkin, oleh sebab itu teknik pengumpulan digunakan dengan wawancara mendalam dan fokus group discession untuk mengkonfirmasi data yang diperoleh agar valid. Subjek (informasi) penelitian adalah para pimpinan komunitas dalam hal ini Ketua RT sebagai pimpinan yang diakui warga. Di samping itu informasi juga diambil dari masyarakat yang ditokohkan dan yang dianggap dapat memberi informasi akurat dalam hal ini informasi diambil dengan teknik snowball sampling. Teknik observasi juga digunakan untuk mengamati kebudayaan warga komunitas Kali Code beserta kegiatan mereka sehari-hari, disamping dokumen-dokumen yang dapat di jadikan data penunjang yang penting untuk kesempurnaan data yang digali. Untuk lebih menjamin keabsahan data dilakukan Tri Anggulasi (Cek dan Recek), juga membadingkan hasil wawancara dengan hasil observasi serta memperpanjang waktu penelitian di Lapangan. 
Data dianalisis dengan teknik kualitatif deskriptif, merupakan penggambaran keadaan yang diperoleh dan kemudian dianalisis dalam bentuk kata untuk memperoleh suatu makna dan kesimpulan. Proses ini di lakukan menggunakan model analisis interaktif seperti yang diungkapkan Miles dan Hubermen, yaitu proses analisis yang dilaksanakan bersamaan dengan proses pengumpulan data. Proses analisis dilaksanakan dalam penelitian kualitatif ini menggunakan empat tahap, yaitu: 1) pengumpulan data, 2) reduksi data, 3) penyajian/display data, dan 4) penarikan kesimpulan. Tahapan-tahapan tersebut merupakan proses saling berkaitan dan interaktif.

\section{PEMBAHASAN}

Paparan hasil penelitian berikut akan disajikan meliputi (1) Profil Pimpinan Komunitas Kali Code Pasca Romo Mangun dan (2) Pola kepemimpinan Komunitas Kali Code dalam mengerakkan Modal sosial.

Dari data yang digali diperoleh informasi bahwa Romo Mangun dapat menggerakkan masyarakat Ledok Kali Code membangun pemukiman secara mandiri dan didasarkan oleh Mosal sosial yang digerakkan Romo Mangun. Modal sosial itu berupa rasa kepercayaan (Trust) yang tinggi terhadap sosok kepemimpinan Romo Mangun, rasa kebersamaan diantara penghuni Ledok Gondolayu Kali Code, mereka menyumbangkan tenaga sebesarbesarnya bagi pembangunan itu dengan bergotong royong berbulan-bulan bahkan tahunan sampai saat ini kebiasaan gotong royong tetap terpelihara. Selain itu berkat janji Romo Mangun dan Tim dana datang dari para Donatur yang simpati atas upaya yang dilakukan Romo Mangun dan Tim beserta para penghuni pemukiman Kali Code. Kepemimpinan komunitas Kali Code (RT dan tokoh masyarakat Kali Code) melanjutkan usaha pembangunan komunitas dengan menggunakan modal sosial. Untuk dapat mengetahui pola kepemimpinan mereka itu, lebih dahulu di ketahui profil mereka. 


\section{Profil Pemimpin Komunitas Kali Code Setelah Romo Mangun}

a. Bapak ST

Bapak ST kurang lebih berumur kira-kira 78 tahun. Beliau mantan RT dari beberapa priode, dari periode pertama kali ketika RT Kali Code Gondolayu ada. Beliau lama menjadi orang kepercayaan Romo Mangun. Sosok tubuhnya besar, tinggi dan kekar. Berwibawa tetapi terkesan keras, tegas, dan berani, dan kalau bicara ceplas ceplos. Ketika muda, beliau terkesan seperti jagoan yang mampu membuat orang menurut dan mematuhinya. Kewibawaan dan kharismatiknya terletak pada sikapnya yang berani, tegas, dan tidak segan-segan langsung menegur yang salah. Namun, di samping sikap keras tersebut beliau dapat menjadi sosok yang melindungi dan membela warganya serta mampu bersikap adil.

Bapak ST menjadi RT sejak awal pemukiman Kali Code diakui sebagai salah satu RT di wilayah RW Gondolayu, Kelurahan Kota Baru. Sebagai RT yang menjabat enam kali berturut-turut, tentu kepemimpinan Bapak ST ini istimewa dan kharismatik. Berikut ini akan dinarasikan pandangan Bapak ST tentang kemampuan seorang pemimpin dalam memimpin warganya, khususnya dalam hal ini warga Code, apa yang harus dimiliki pemimpin dan bagaimana beliau mampu menggerakkan warganya untuk memberi modal bagi pembangunan pemukiman Kali Code, baik berupa tenaga, dana maupun rasa memiliki terhadap kampung mereka.

Sejak masa awal pemukiman Kali Code dibangun, ditata fisiknya, dan dibina warga penghuninya di bawah kepemimpinan Romo Mangun, Bapak ST telah diangkat menjadi RT. Bapak ST adalah salah satu warga pemukiman Kali Code yang waktu itu dianggap sebagai penghuni liar oleh pemerintah DIY dan warga sekitarnya. Dia menyebut masa awal itu sebagai masa sulit "Glagah alang-alang". Menurut beliau seorang pemimpin itu yang bisa menilai adalah warganya. Wargalah yang dapat menilai bagaimana pemimpin bertindak, baik atau tidak baik. Apakah pemimpin itu 
bisa "ngemong" atau tidak. Bila pemimpin tidak benar, maka seberapa jauh warga berani memberi masukan, saran, dan nasehat bahkan menyalahkan pimpinan. Begitu pula sebaliknya, apakah pemimpin berani menegur warga yang salah dan memberi pencerahan untuk mereka sadar bahwa mereka mereka itu salah, sehingga dapat berubah menjadi benar. Menurut Bapak ST semua tergantung pada pribadi pemimpin. Kalau ada warga yang salah jangan langsung dihukum tetapi dituntun untuk menjadi benar. Seperti yang dikemukakan beliau di bawah ini.

“...menurut saya yang menilai pimpinan itu mampu atau tidak, baik atau tidak, benar atau salah adalah warga yang dipimpin dan bukan pimpinan itu sendiri. Seorang pemimpin harus bisa "ngemong" dan tidak langsung menghukum warganya bila berbuat salah, tetapi harus mampu memberi jalan untuk mereka dapat bertindak benar. Pemimpin pun perlu teguran, nasehat dan kritikan dari warga, apabila beliau salah melangkah, sebaliknya pemimpin pun harus berani menegur, menasehati, atau bertindak tegas bila ada warga yang melakukan kekeliruan yang merugikan komunitasnya".

Dari apa yang dikemukakan Bapak ST di atas dapat diketahui bahwa sebagai pimpinan Bapak ST memiliki kewibawaan, ketegasan, dan keberanian untuk menegakkan kebenaran. Di samping itu sebagai pemimpin beliau memiliki rasa keadilan, mampu mendengar, peduli dan memelihara hubungan (ngemong) pada warganya. Selanjutnya beliaupun dapat berlaku demokratis yang dibuktikan memberi kesempatan untuk dikritik, dinasehati, dan diberi saran oleh warganya. Jadi tidak hanya beliau sebagai pemimpin yang boleh mengkritik, menasehati dan memberi saran, tetapi warga sebagai orang yang dipimpin memiliki hak yang sama. Kebersamaan merupakan hal yang penting.

Bila dikaitkan dengan tipe kepemimpinan maka beliau termasuk gaya kepemimpinan yang berpola mementingkan pelaksanaan hubungan kerja sama. Sebagai pemimpin, beliau 
menaruh perhatian besar dan keinginan yang kuat agar setiap orang mampu menjalin kerja sama dan melaksanakan tugas masingmasing, yang tidak dapat dilepaskan dari kebersamaan di dalam suatu komunitas sebagai satu kesatuan (Hadari dan Martini, 2006).

Tipe kepemimpinan ini menekankan pada prinsip setiap orang harus mampu menjalin kerja sama dengan para pimpinan, baik menjadi atasan langsung maupun pimpinan unit, dalam hal ini di Kali Code dikenal dengan Tri Bina. Pemimpin seperti Bapak ST percaya bahwa dengan kerja sama yang intensif, efektif, dan efisien, semua tugas dapat diselesaikan secara maksimal. Hal inipun dikemukakan oleh Bapak ST sebagai berikut.

“...warga di Kali Code selalu saya tekankan pada keinginan untuk bekerja sama dan guyup. Sebagai contoh ketika kami membangun kampung kami, kami gotong royong mencari batu dan bambu di bawah kendali Romo Mangun. Sampai akhir kepemimpinan saya menjadi RT sebanyak 6 kali berturut-turut kebersamaan, guyub dan musyawarah sudah menjadi cirinya...".

Selanjutnya beliau menambahkan dalam membangun Kampung Kali Code terutama untuk sarana umum, ternyata kendala yang besar adalah dana, maka Bapak ST menggerakkan warganya untuk bahu membahu menutupi segala keperluan dengan usaha bersama, termasuk menggalang sumbangan yang berupa tenaga, uang, pikiran agar apa yang diperlukan dapat dibangun. Hal ini diungkapkan Bapak ST dengan penuh semangat sebagai berikut.

“...di sini semuanya dengan musyawarah untuk menyelesaikan masalah bersama. Misalnya kita akan membangun sarana umum ternyata uang tidak mencukupi, maka kami berdiskusi bagaimana cara penyelesaiannya, sebagai contoh ketika kami akan membangun masjid, ternyata biaya tidak mencukupi, maka saya selaku pemimpin menegaskan akan bertanggung jawab penuh meski tidak ada bantuan pemerintah. Saya katakan, 'Kalau demi kebaikan bukan untuk kejelekan, apapun 
akan saya lakukan dan saya siap bertanggung jawab'. Alhamdulillah, setelah bekerja keras, akhirnya masjid selesai dibangun meski dengan swadaya dan perjuangan...".

Apa yang dikemukakan Bapak ST ini, sesuai dengan yang dikemukakan Putnam (1993), bahwa modal sosial merujuk pada bagian dari organisasi sosial, seperti kepercayaan, norma, dan jaringan, yang dapat meningkatkan efisiensi masyarakat dengan memfasilitasi tindakan-tindakan terkoordinasi. Lebih tepatnya, modal sosial memberi sumbangsih pada tindakan kolektif dengan meningkatkan biaya potensial bagi para pengikut, memfasilitasi, berkomunikasi dengan tepat dan mendorong kolaborasi yang potensial. Bapak ST tahu betul tentang kondisi dan perangai warganya, beliau memanfaatkannya demi membangun kemajuan bersama.

\section{b. Profil dan Kepemimpinan Bapak Dsn}

Bapak Dsn adalah mantan ketua pembangunan Kali Code, orang kepercayaan Romo Mangun. Sosok beliau kecil, agak kurus, diam berwibawa, sangat terkesan intelektual dan cerdas. Walaupun beliau bukan alumnus perguruan tinggi, tetapi itulah kesan warga terhadap Bapak Dsn. Beliau selalu menjadi tempat warga bertanya, bahkan bapak-bapak RT Kali Code sangat percaya pada pendapatpendapat beliau. Sikap beliau yang tenang dan berwibawa membuat warga percaya pada apa yang beliau sarankan, beliau banyak memberi pengetahuan pada warga melalui keteladanan. Hal ini beliau kemukakan sebagai berikut.

“...pemimpin dalam memimpin yang penting adalah keteladanan, termasuk untuk para warga Kali Code. Untuk menanamkan rasa kebersamaan, kepercayaan, ketertiban, kerelaan, dimulai dari keteladanan para pemimpin dan tokohtokoh masyarakatnya".

Bapak Dsn memiliki tipe kepemimpinan yang berpola mementingkan pelaksanaan hubungan kerja sama. Di mana beliau 
menaruh perhatian besar dan keinginan yang kuat agar setiap orang mampu menjalin kerja sama dalam melaksanakan tugas masingmasing. Beliau tipe orang yang tenang dan cerdas, lebih berkeinginan untuk mengembangkan kerja sama yang harmonis, sehingga setiap anggota komunitas Kali Code mau mengerjakan apa yang harus mereka kerjakan, dan bekerja sama dalam mengerjakan sesuatu demi kebersamaan. Dalam konteks ini para pimpinan dan warga yang ditokohkan masyarakat harus mampu menjadi teladan. Pengarahan yang diberikan Bapak Drn ini lebih pada tindakan-tindakan nyata, produktif yang dapat dilihat warga, sehingga dengan melihat contoh teladan warga akan mengikutinya.

Bila dikaitkan dengan teori bentuk perilaku kepemimpinan yang dikemukakan Hadari (2006), Bapak Dsn termasuk pada kepemimpinan pelindung dan penyelamat (missionary), sebab beliau menunjukkan sikap dengan indikator: (a) pemimpin berkepribadian ramah, tenang, dan menyejukkan. Perilaku itu didasari asumsi bahwa hubungan manusiawi yang efektif berbentuk persahabatan yang akrab melebihi segala-galanya, dalam mewujudkan eksistensi kelompok yang bertujuan memberikan bantuan dan pertolongan pada orang lain yang memerlukan. Ini terlihat dari sikap beliau sehari-hari. Beliau juga menunjukkan sikap (b), pemimpin selalu berusaha secara aktif mencegah pertentangan, menghindari perdebatan, dan konflik-konflik dengan orang lain, di dalam maupun di luar organisasi. Dengan demikian berarti simpati dan penerimaan orang lain dipandang sebagai awal dari sukses mewujudkan usaha membantu dan menolong orang lain yang dipandang perlu, baik diminta atau tidak. Selain itu dalam bertindak Bapak Dsn ini, dekat dengan ciri, yaitu (c) melaksanakan tugas-tugas secara santun, agar dapat menghindari tekanan emosional/psikis pada orang-orang yang dibantu atau ditolong. Kesantaian terutama dimaksudkan menghindari formalitas dan birokrasi yang tidak perlu, sehingga orang yang dibantu merasa diakui dan dihormati keberadaannya, melalui pelayanan yang bersifat manusiawi. 
Hal ini juga tergambar pada sikap beliau ketika diwawancarai dan kata-kata yang beliau ucapkan. Sebagai orang yang sangat dipercaya oleh Romo Mangun (pada saat Romo Mangun ada di Kali Code), beliau banyak meneladani tingkah laku Romo yang sangat dikenal sebagai seorang misionari yang teguh membela kepapaan. Beliaupun dalam bertindak lebih mengutamakan rasa kemanusiaan. Sebagai contoh ketika ditanya bila ada warga pemukiman Kali Code, yang tidak mau ikut aturan ataupun tidak mau berpartisipasi untuk pembangunan kampung, beliau dengan santai mengatakan sebagai berikut.

“...lama-lama juga ikut...kita beri pengertian bahwa semua yang dilakukan warga, juga untuk dapat dimanfaatkan warga, termasuk yang kita nasehati tersebut. Kalau kita peduli dengan lingkungan, maka lingkungan juga peduli dengan kita...kalau sekali, dua kali, belum juga ikut ya kita tetap mendekati mereka dengan itikat baik. Tidak perlu dengan hukuman, karena itu akan lebih menjauhkan mereka dari kita...".

Begitu pula ketika ditanya, bagaimana menanamkan nilainilai yang baik, kebersamaan, kepedulian pada warga Kali Code yang memiliki latar belakang sangat beragam dan umumnya dulu hidup dalam kekerasan, maka beliau mengatakan sebagai berikut:

“...semua dimulai dari keteladanan para pemimpin dan tokohtokoh masyarakat pemukiman Kali Code. Sebenarnya menurut saya, warga Kali Code ini sangat patuh pada Pak RT (pemimpin warga), kalau Pak RT tegas, maka semua manut...Bagi saya yang penting warga akur dan tidak saling konflik. Bila ini dapat terlaksana maka pembangunan pun akan dapat terlaksana dengan baik, sebab warga adalah modal utama pembangunan pemukiman Kali Code ini...”.

Dari apa yang dipaparkan di atas, maka dapat dikatakan bahwa modal sosial untuk pembangunan perkampungan warga Kali Code adalah masyarakatnya. Untuk menggerakkan modal sosial 
tersebut maka dibutuhkan pimpinan yang dapat diteladani dan memiliki kewibawaan untuk diikuti. Bila pimpinan dapat dipercaya dan mampu memberi contoh maka wargapun akan mengikuti serta dapat dijadikan modal yang besar untuk membangun lingkungan. Dengan demikian dalam menggerakkan modal sosial dalam hal ini warga, diperlukan keteladanan, anjuran dan kewibawaan (kharismatik).

\section{c. Profil dan Kepemimpinan Bapak Drn}

Bapak Drn adalah RT 01 Kali Code saat ini. Sosok beliau gagah, cekatan, dan intelek, sebab beliau adalah lulusan perguruan tinggi dari Universitas Negeri Yogyakarta. Istrinya juga sarjana dan anaknya pun kuliah di Universitas Gadjah Mada. Keluarga ini merupakan teladan di sekitar perkampungan Kali Code, hanya ada 2 orang yang sekolah sampai perguruan tinggi saat wawancara dilaksanakan. Untuk tahun 2010 ini Bapak Drn juga berencana mengkuliahkan putrinya ke perguruan tinggi.

Sehari-hari Bapak Drn ini bekerja wiraswasta dengan membuka bengkel elektronik, sedang istrinya yang sarjana pendidikan tersebut sebagai ibu rumah tangga. Sebagian besar waktu mereka memang banyak digunakan untuk kepentingan warga Kali Code. Bermacam-macam kegiatan yang ada di Kelurahan Kota Baru selalu mereka ikuti sebagai konsekuensi dari kepercayaan warga yang memiliki Bapak Drn sebagai pimpinan RT dan Ibu Drn sebagai ketua PKK kampung Kali Code Gondolayu.

Menurut Bapak Drn menjadi seorang pimpinan dibutuhkan kemampuan intelektual maupun non intelektual, misalnya kemampuan bermasyarakat, toleransi, dan merasakan. Seperti yang beliau kemukakan berikut ini.

"Jadi pemimpin itu harus mumpuni, baik dari intelektual atau non intelektual, mampu merukunkan warga, mampu membuat guyub, mampu meningkatkan solidaritas dan solitas (solit=kompak), mampu menumbuhkan kebersamaan antar warga, mampu memberi keteladanan dalam arti positif...selain 
itu pemimpin harus mampu menjadi penengah, fasilitator antara sesama warga yang berbeda agama dan juga terhadap generasi muda agar mereka ingin memiliki pendidikan yang baik".

Dari pernyataan beliau yang terarah ini, dapat dikatakan Bapak Drn ini memiliki kepemimpinan yang kharismatik, disegani. Warga Ledok Kali Code segan pada beliau karena sikap beliau yang tegas, menerapkan aturan yang sudah disepakati warga dan beliau juga mampu berargumentasi dengan efektif ke warga dan ke pemerintah kelurahan, kecamatan, dan kota Yogyakarta.

Sebagai kampung yang dulu terkenal kumuh dan kurang menerapkan aturan norma kepatuhan dan agama, maka pemimpin dalam hal ini harus tegas tetapi komunikatif. Sehingga pendekatan yang tepat harus dilakukan. Hal ini dikemukakan ketika beliau ditanya bagaimana beliau mengatasi hal-hal yang mengganggu ketertiban, seperti yang dikatakannya di bawah ini.

"...dulu pemuda di sini sering mabuk-mabukan, banyak warga yang saling "demen" dengan suami/istri tetangganya, tetapi sekarang sudah tidak boleh lagi. Larangan tersebut memang tidak berupa aturan tertulis namun sudah menjadi kesepakatan bersama...saya mengatasinya dengan berbicara dengan hati dan logika dengan mereka... dari cara yang halus sampai cara yang keras pernah saya lakukan... akhirnya lambat laun mereka sadar dan sekarang sudah jarang sekali terjadi”.

Menurut Bapak Drn, kampung Ledok Kali Code, masyarakatnya guyub sekali. Terutama kalau digerakkan saat kerja bakti pasti banyak yang datang dan berpartisipasi. Kadang kerja bakti itu ditargetkan 1 atau 2 jam, tetapi banyak warga kerja baktinya sampai sore. Biasanya Bapak Drn memberi mereka makanan dan rokok sebagai tanda simpati beliau.

Bapak Drn selalu ingat dengan keinginan Romo Mangun untuk dapat mewujudkan warga Kali Code yang berpendidikan, walau hidup mereka saat ini termasuk masih pas-pasan. Beliau mengeluhkan sikap pemerintah yang kurang membantu warga 
untuk mendapat kebijakan KMS, seperti yang beliau katakan di bawah ini.

“...untuk mewujudkan warga Kali Code agar berpendidikan banyak kendala dari pemerintah yang kami rasakan, terutama bantuan biaya. Banyak warga kami yang sebenarnya memenuhi syarat mendapat bantuan yang sesuai dengan kebijakan KMS, tetapi tiba-tiba saja dicoret oleh Pemerintah Kota (Pemkot) dengan dalih berdasarkan data BPS, mereka tidak termasuk kriteria penerima KMS...tapi menurut saya data Pemkot tidak valid dan mengapa tidak ada crosscheck atau konfirmasi dengan saya. Tetapi saya tidak mau menyerah, saya terus perjuangkan kepentingan warga saya, akhirnya beberapa nama yang dicoret dengan perjuangan keras yang saya lakukan bisa ikut menerima KMS, yang benar-benar adalah hak mereka sebagai santuan dari pemerintah".

Dari apa yang dikemukakan di atas, sangat jelas Bapak Drn ini adalah pimpinan yang sangat memikirkan dan mampu mengayomi warganya. Namun dari warga pun beliau meminta tanggung jawab demi kebaikan bersama, seperti yang beliau paparkan di bawah ini.

"Kewajiban seluruh warga pemukiman Kali Code (RT 01) ini adalah menjaga kebersihan, termasuk kebersihan Kali Code, menjaga ketertiban lingkungan dengan hidup saling menghargai dan membantu, memelihara semangat kebersamaan, memiliki tanggung jawab pada apa yang dilakukan dan pada keluarga serta lingkungan dan sama-sama memelihara ketertiban...kalau nilai-nilai ini dijaga bersama, maka kampung kami ini tidak akan dimasuki orang-orang yang tidak diinginkan. Sementara orang yang datang ke sini merasa nyaman dan terkesan baik".

Kebersamaan selalu ditonjolkan oleh Bapak Drn dan juga oleh pimpinan yang diwawancarai sebelumnya. Pimpinan yang meletakkan kebersamaan adalah hal yang sangat penting termasuk 
pada tipe kepemimpinan yang berpola mementingkan hubungan kerja sama. Pemimpin menaruh perhatian yang besar dan keinginan yan gkuat agar setiap orang mampu menjalin kerja sama.

\section{Pola Kepemimpinan dan Modal Sosial}

Dari apa yang dipaparkan pada bagian kepemimpinan Kali Code masa Romo Mangun dan pimpinan sesudah Romo Mangun, maka dapat kita simpulkan bahwa peran pemimpin dalam menggerakkan modal sosial masyarakat sangat besar: (1) pemimpin harus berdiri di depan menjadi pemula, menjadi contoh/teladan yang harus terjun langsung mengerjakan bersama-sama; (2) pemimpin harus mampu meyakinkan warga untuk mau menyumbangkan tenaga mereka demi kepentingan bersama; (3) pemimpin harus bisa mengarahkan apa yang harus dikerjakan, walaupun keputusan dimusyawarahkan, namun ide-ide, gagasangagasan, dan cara sebagian besar lahir dari pemikiran pimpinan; (4) pimpinan harus bersikap tegas dan rela berkorban demi warga, sehingga mereka merasa yakin dengan keikhlasan pimpinannya. Agar warga tidak ragu-ragu dalam mengikuti dan berpartisipasi terhadap apa yang sudah disepakati; (5) pemimpin harus persuatif dan memiliki strategi memimpin, dengan mengenali warganya yang beragam latar belakang. Mampu mencari cara agar wargapun menjadi rela berkorban untuk kepentingan bersama; (6) pemimpin harus tegas dan berwibawa dalam memimpin, aturan yang sudah disepakati bersama dipegang dan dijalankan; (7) pemimpin mampu meyakinkan bahwa kegiatan yang mereka laksanakan ini akan berhasil dan bermanfaat; (8) pemimpin harus dapat meyakinkan warga bahwa warga dapat melaksanakan. Sikap optimis pemimpin sangat berpengaruh pada sikap optimis dan semangat warga yang dipimpin; (9) pemimpin dapat menunjukkan tanggung jawab dan siap menanggung resiko yang akan ditimbulkan; (10) pemimpin mampu menjadi juru bicara ke bawah dan ke atas, terutama pada saat-saat yang benar-benar dibutuhkan. 
Kesepuluh peran tersebutlah yang sudah dijalankan para pimpinan Kali Code, sejak kepemimpinan Romo Mangun, Bapak ST, Bapak Dsn, dan Bapak Drn. Kepemimpinan mereka benarbenar dirasakan manfaatnya bagi warga Kali Code. Sosok mereka sangat dihormati oleh warga. Dengan demikian dapat dikatakan tipe kepemimpinan komunitas Kali Code ini adalah kharismatik, gaya kepemimpinannya mementingkan pelaksanaan hubungan kerja sama, perilaku kepemimpinan mereka adalah pelindung dan penyelamat (missionary). Dengan kepemimpinan yang demikian para pemimpin ini dapat menggerakkan modal sosial masyarakatnya, yang umumnya orang-orang kurang mampu, kurang berpendidikan, kurang pengalaman, kurang mengetahui norma-norma dan nilai-nilai kemasyarakatan yang ditinggikan dalam kehidupan. Dengan keterbatasan-keterbatasan tersebut ternyata di bawah kepemimpinan para pemimpin di tas mereka dapat berubah cara hidup, cara berpikir, dan mampu menata kampung kumuh, liar dan tidak diakui, menjadi kampung yang relatif layak huni, bertata nilai dan diakui keberadaannya di wilayah Kota Yogyakarta.

a. Pemimpin Memiliki Tipe Kepemimpinan Kharismatik

Di atas telah disimpulkan bahwa keempat pimpinan Kali Code dapat menggerakkan masyarakat sebagai modal sosial pembangunan pemukiman Kali Code memiliki tipe kepemimpinan kharismatik. Kharismatik dalam Kamus Besar Bahasa Indonesia berarti sifat karisma. Sedang perkataan kharisma diartikan sebagai "keadaan atau bakat yang dihubungkan dengan kemampuan yang luar biasa dalam hal kepemimpinan seseorang untuk membangkitkan pemujaan dan rasa kagum dari masyarakat terhadap dirinya "atau disebut kepemimpinan yang didasarkan atas kualitas kepribadian individu” (Hadari dan Martini, 2006).

Sejalan dengan hal di atas maka kepemimpinan kharismatik dapat diartikan sebagai "kemampuan menggerakkan orang lain dengan mendayagunakan keistimewaan atau kelebihan dalam 
sifat/aspek kepribadian yang dimiliki pemimpin, sehingga menimbulkan rasa hormat, segan dan kepatuhan pada orang yang dipimpinnya. Hal ini sangat jelas dapat dilihat dari sosok Romo Mangun, sebagai pemimpin Kali Code di awal. Pada saat itu pemukiman Kali Code dianggap liar, dan penghuninya terdiri dari pendatang yang sebagian besar preman, pengangguran, pencuri, pemulung, WTS jalanan yang selalu dianggap sebagai biang dari permasalahan sosial. Para penghuni ini juga umumnya adalah pasangan kumpul kebo (suami istri tanpa nikah), suka berjudi, dan mabuk-mabukan, serta sangat kurang dalam mengenal norma susila maupun agama. Dengan kharisma Romo Mangun, para penghuni iji mulai dibina dan dikenalkan hidup yang normal, hidup yang sehat dan hidup yang bersusila.

Selain itu keistimewaan kepribadian yang umum dimiliki pimpinan kharismatik adalah akhlak yang terpuji, sehingga perilaku kepemimpinannya terarah sepenuhnya pada kepentingan orangorang yang dipimpin, baik perseorangan maupun kelompok. Semua pemimpin komunitas Kali Code yang telah dipaparkan sebelumnya, yaitu Romo Mangun, Bapak ST, Bapak Dsn, dan Bapak Drn adalah orang-orang yang menurut para warga adalah orang yang mereka hormati, kagumi, dan tingkah laku mereka dapat diteladani. Hal inilah yang dikemukakan oleh warga yang diwawancarai, ketika ditanyakan kriteria pemimpin yang bisa menjadi pemimpin di lingkungan pemukiman Kali Code satu di antaranya Ibu Ttk, sebagai berikut:

“...kriteria pemimpin yang dapat memimpin warga Kali Code ini adalah pemimpin yang memiliki tingkah laku baik dan dapat jadi contoh. Pemimpin itu jujur, adil tidak membeda-bedakan dan pilih kasih. Pemimpin itu juga ramah pada warganya dan selalu memperhatikan kebutuhan para warganya. Keteladanan pemimpin dari sikap, tingkah laku, dan pemikiran-pemikiran cerdas mereka sangat dibutuhkan para warga untuk dijadikan panutan". 
Dengan kharisma para pemimpin komunitas Kali Code ini, maka modal sosial yang ada dapat dimanfaatkan demi pembangunan bersama. Warga tidak pernah membantah atau menolak tiap gagasan yang dilontarkan pimpinan mereka, sebab mereka percaya pimpinannya adalah orang yang dapat dipercaya. Pemimpin dapat membentuk budaya komunitasnya melalui tindakan sehari-hari. Pemimpin harus bisa menunjukkan ada kesesuaian dari apa yang dilakukan dengan yang dikatakan (Triantoro S., 2004).

b. Pemimpin Menumbuhkan Rasa Kebersamaan Warga

Hampir semua para informan yang diwawancarai berpendapat, bahwa semua yang mereka bangun dalam pemukiman Kali Code adalah hasil kerja bakti, hasil kerja keras bersama. Demikian pula pengakuan para pimpinan Kali Code, bahwa semua modal sosial yang paling berperan membangun pemukiman adalah kerja bakti. Hal ini dinyatakan oleh salah seorang tokoh masyarakat Kali Code, yang sejak awal Romo Mangun sudah ikut terlibat dalam pembangunan penataan pemukiman Ledok Kali Code, sebagai berikut.

“...semua sarana dan tempat tinggal warga dibangun dengan gotong royong, mulai dari masa kepemimpinan Romo Mangun ... ya kebiasaan gotong royong ditanamkan sejak jaman Romo Mangun. Dulu waktu itu, membangun kampung kami diminta gotong royong mencari bambu dan batu...".

Kerja bakti dan gotong royong adalah manifestasi rasa kebersamaan dan guyub. Di masyarakat Kali Code kontrol sosial sangat kental. Bila ada warga yang tidak mau ikut gotong royong kerja bakti, biasanya 'dioyak-oyak' (dikejar-kejar) oleh warga yang lain. Jaadi jarang sekali ada warga yang tidak ikut berpartisipasi.

Selain dalam bentuk kerja bakti, kebersamaan juga ditunjukkan dengan iuran sosial dan kematian. Iuran sosial digunakan apabila ada warga yang sakit dan iuran kematian ditujukan untuk keluarga warga yang ditimpa musibah kematian. 
Iuran sosial dan iuran kematian juga ditopang dengan hasil jimpitan beras. Jimpitan adalah suatu kewajiban dari setiap keluarga, yaitu dengan menyediakan wadah berisi sejimpit beras yang diletakkan di depan rumah, yang akan diambil oleh orang-orang yang bertugas menjaga malam. Beras jimpitan dikumpulkan kalau sudah banyak dijual dan uangnya untuk menambah kas bersama.

Rasa kebersamaan tersebut juga diwujudkan warga Kali Code dalam suatu organisasi masyarakat Kali Code yang mereka namakan "Paguyuban Manunggaling Tekad Agawe Sentosa" (Paguyuban Bersatunya Tekad Membangun Kekuatan). Sesuai dengan namanya, organisasi itu ditujukan untuk membangun rasa persaudaraan dan persatuan masyarakat perkampungan Kali Code melalui pertemuan, kerja bakti, "macapatan" (menyanyikan puisipuisi Jawa) dan lain-lain.

Kesadaran untuk guyub atau mengutamakan kebersamaan, ditanamkan semua pimpinan komunitas pemukiman Kali Code yang dengan jiwa Altruis atau membela kaum terpinggirkan (marginal), menyadarkan warga bahwa tanpa kesadaran kebersamaan (guyub), mereka akan lemah tak berdaya. Semangat itu terus dihidupkan oleh pimpinan dan menjadi dasar dari semua kegiatan. Itulah sebabnya semua kegiatan dilaksanakan dengan kerja keras bersama, kerja bakti, iuran bersama walaupun jumlahnya sangat terbatas. Tanpa arahan dan dukungan para pemimpin dan tokoh masyarakat yang memiliki jiwa Altruis tersebut, kebersamaan sebagai modal sosial sulit digerakkan di pemukiman Kali Code, mengingat latar belakang warga pendatang yang sangat beragam watak dan perangainya.

\section{SIMPULAN}

Peran kepemimpinan komunitas Kali Code dalam menggerakkan modal sosial sangat besar. Warga mudah mengikuti apa yang disarankan dan diarahkan para pimpinan ini, sebab pemimpin komunitas ini memiliki kepribadian yang dapat 
dipercaya, bersikap tegas dan rela berkorban. Para pemimpin ini juga dapat menjadi juru bicara yang efektif, baik ke bawah kepada para anggota komunitas dan ke atas kepada pemerintah. Umumnya modal sosial yang ada di sana berupa kerelaan menyumbangkan tenaga (kerja bakti) dan rasa kebersamaan.

Dikaitkan dengan tipe-tipe kepemimpinan secara teoritik kepemimpinan komunitas Kali Code termasuk tipe kepemimpinan kharismatik, di mana kharismatik ini bersumber dari kepribadian mereka yang terpuji dan diakui serta dihormati oleh para warga. Pemimpin dengan kekuatan kepribadian mereka mampu menumbuhkan rasa kebersamaan dan manfaatnya.

\section{DAFTAR PUSTAKA}

Dharmawan, Arya Hadi. 2002. Kemiskinan Kepercayaan (the povery of Trust), Stok Modal Sosial dan Disintegrasi Sosial. Paper Seminar dan Kongres Nasional IV Ikatan Sosiologi Indonesia (ISI) Bogor, 27-29 Agustus 2002.

Fukuyama, F. (2002). Social CapitalCivil Society and Development Third World Quarterly, 22, 1, 7-20.

Prusack, L. dan Cohen D. 2001. How to Invest in Social Capital. Harvard Bussines Review, 79, 6, 67-93.

Khudori, Darwis. 2001. Menuju Kampung Pemerdekaan. Yogyakarta: Yayasan Pondok Rakyat.

Coleman, James. 1999. Social Capital in the Creation of Human Capital. American Journal of Sociology 94 (Suplement): S95-S210.

Putnam, Robert D. 2000. 1993. The Prosperous Community: Social Capital and Public Life. The american Prospect. 4, 13, 118. 
Jurnal Penelitian Humaniora, Vol. 16, No.1, April 2011: 22-44

Durkheim, Emile. 1933. The Devision of Labor on Society. Terjemahan oleh George Simpson. New York: the Free Press.

Hadari dan Nawawi. 2006. Kepemimpinan Yang Efektif. Gadjah Mada University Press. 